\title{
Izolacja w firmie
}

\section{Ewa Szkudlarek}

ORCID: OOOO-OOOI-574I-I984

(Uniwersytet im. Adama Mickiewicza w Poznaniu)

Termin „firma” z uwagi na zakres pola semantycznego jest znacznie węższy niż „organizacja”, choć niewątpliwie mieści w sobie wszelkie cechy typowe dla tej drugiej. Bez względu na ograniczenia tekstualnej metafory, faktem pozostaje to, że z tego punktu widzenia możemy odkryć głębsze obszary życia firmy i rozpoznać kody wpisane w jej strukturę. „Budynek firmy”, „praca w firmie”, „dziedzictwo firmy”, ,ja - firma”, wszystkie te wyrażenia określają z jednej strony relacje przestrzenne, zawodowe, z drugiej zaś - ideowe i związane z doświadczeniem sukcesu.

W perspektywie socjologicznej i psychologicznej firma może być postrzegana jako szeroko rozumiana przestrzeń mityczna, zapewne przez to, że w układzie pięter, działów, korytarzy, gabinetów dochodzi do realizacji przestrzennej motywu labiryntu. Bez względu jednak na konkretną formę labiryntowego zagęszczenia, firma jest społecznym mitem, ucieleśnieniem pewnych wyobrażeń wielkiej kariery i drogi sukcesu. Coraz częściej pojawia się tendencja do postrzegania firmy jako miejsca spotkań ludzi i budowania nie tylko nowych obiektów, lecz również warunków twórczych interakcji i relacji interpersonalnych. Firma pełni zatem także funkcję medium komunikacji społecznej. Oczywiście paradoksalność sytuacji ludzkiej pozostaje niezmieniona - społeczne (informacyjne) zbliżenie nie oznacza automatycznego przekroczenia barier samotności, wyalienowania. Organizacja chroni prywatność oraz teoretycznie łatwy dostęp do innych, ale też separuje jednostki, czyniąc je potencjalnymi zakładnikami lub po prostu więźniami swoich pozycji w systemie. Ten proces przyczynia się do zawłaszczenia prywatnego czasu i przestrzeni życiowej pracownika, co w konsekwencji deprecjonuje mit sukcesu $\mathrm{w}$ postaci intratnej posady $\mathrm{w}$ firmie. Funkcjonalne rozplanowanie przestrzeni $\mathrm{w}$ danym budynku - mimo istniejącej koncepcji instytucji otwartej - oznacza zamknięcie środowiska $\mathrm{w}$ relatywnie precyzyjnie zakreślonym obszarze. Takie położenie stwarza warunki do powstania sytuacji odosobnienia. W początkowej fazie jest to 
izolacja przestrzenna, później społeczna, a w konsekwencji także osobowa. Jednak $\mathrm{w}$ ostatecznym rozrachunku firma i tak jest postrzegana jako miejsce pracy, staje się czymś prywatnym w tym sensie, że nieuchronnie egzystuje w świadomości pracowników jako i c h firma, będąca sceną niepowtarzalnych konstelacji zdarzeń i zmagań konkretnej jednostki. Dla jednych stanie się miejscem teraźniejszej pracy, dla innych obietnicą sukcesu w niedalekiej przyszłości. Do podobnego wniosku doszedł w wywiadzie prasowym Hector Laing, były prezes United Biscuits: „Maszyny zużywają się. Samochody zżera korozja. Ludzie umierają. Ale marki żyją dalej”. Tadeusz „Tad” Witkowicz, założyciel trzech firm (Artel Communications, CrossComm Corporation, Adlex) i jeden z najbogatszych polskich emigrantów stwierdził natomiast: „Dzisiaj już nikt mi nie imponuje tym, jakie ma wykształcenie lub nazwisko, co mówi, co o nim piszą, z kim gra w golfa, ile ma pieniędzy lub sławnych przyjaciól. Wszystko to jest opakowaniem. Prawdziwą, wymierną oceną człowieka są jego czyny, osiągnięcia i wyniki - tego nauczył mnie własny biznes”². Firma staje się widzialnym znakiem czynu człowieka, jego pracy, zaangażowania, porażek i sukcesów, a także ideą, dostrzegalnym i czytelnym znakiem świata biznesu.

Organizacja - firma - instytucja, jak większość zjawisk życia społecznego, jest monetą lub raczej kostką do gry, która nieustannie ukazuje zmienne oblicza oraz swoistą przypadkowość rezultatów. Egzystencja w firmie może obrócić się w nieoczekiwany sukces jednostki, ale $\mathrm{w}$ wielu sytuacjach prowadzi też do alienacji człowieka ${ }^{3}$.

Struktura, hierarchizacja, zasady funkcjonowania, metody kierowania, wreszcie nadzór i kontrola w odniesieniu do organizacji pozwalają rozszerzyć typologię jej metafor: organizacja jako państwo faszystowskie (żartobliwe ujęcie Naomi Klein, które powstało w wyniku obserwacji społecznych zachowań), organizacja jako instytucja totalna ${ }^{4}$ (instytucja zamknięta - closed institution, której jedną z cech

1 N. Klein, No logo, tłum. H. Pustuła, Izabelin 2004, s. 214.

2 Milioner na mecie. Z Tadem Witkowiczem rozmawia Zbigniew Domaszewicz, "Gazeta Wyborcza” z 19 lutego 2007 r., DF nr 7/718, s. 17.

3 Alienację człowieka w teorii państwa Jeana-Jacques'a Rousseau i we współczesnym totalitaryzmie przedstawił Erich Fromm, zob. idem, Zdrowe spoteczeństwo, tłum. A. Tanalska-Dulęba, Warszawa 1996, s. 128-158, 195-212.

4 Instytucja totalna, czyli zamknięta - oznacza miejsce, w którym realizują się trzy główne sfery życia, normalnie oddzielone: praca, zabawa, sen; przy czym cała aktywność człowieka jest z góry zaplanowana. Erving Goffman wyodrębnil kilka rodzajów instytucji totalnych. Pierwsza grupa to instytucje powołane do opieki nad ludźmi, którzy nie potrafią egzystować i funkcjonować bez pomocy innych (domy starców, przytułki). Drugą grupę tworzą instytucje powołane do opieki nad ludźmi, którzy nie potrafią troszczyć się o siebie, choć nie z własnej winy, ponadto mogą stanowić potencjalne niebezpieczeństwo (szpitale psychiatryczne, sanatoria przeciwgruźlicze). Trzecią grupą są instytucje powołane do ochrony społeczeństwa przed ludźmi, którzy zagrażają mu świadomie i bezpośrednio (zakłady poprawcze, więzienia, obozy koncentracyjne). Czwartą grupę stanowią instytucje powołane do realizacji określonych zadań badawczych, technicznych, obronnych, są zamknięte wyłącznie ze 
charakterystycznych, według Ervinga Goffmana, jest izolacja). Naomi Klein w książce No logo pisze: „obraz korporacyjnej przestrzeni jako faszystowskiego państwa, w którym my wszyscy salutujemy przez logo i nie bardzo możemy krytykować istniejący stan rzeczy, [...] nie oznacza to jeszcze, że już żyjemy w koszmarnej wizji Huxleya"s. Mimo żartobliwego tonu i nieco ironicznej perspektywy autorka dostrzega istotny problem - absolutne podporządkowanie organizacji i permanentne uzależnienie od marki, a więc w pewnym sensie „uwięzienie” zarówno fizyczne, jak i psychiczne. Koncepcja Goffmana pozwala natomiast określić firmę jako instytucję totalną.

Firma jako organizacja wchodzi w skład instytucji powołanych do konkretnych zadań, a w tym przypadku służy rozwojowi gospodarki. Ponadto jest ona zamknięta ze względów instrumentalnych (dzielnice biznesu, budynki monitorowane, ochrona, karty identyfikacyjne) i izolowana (ograniczenie kontaktu ze środowiskiem zewnętrznym, kontrola personelu, całodobowy nadzór). Egzystencję w instytucji totalnej charakteryzuje odosobnienie. W środowiskach odizolowanych należy zwrócić uwagę na izolację jednostki. W bardzo dużym uproszczeniu można przyjać, że ze względu na cel, charakter i zaangażowanie firma jest instytucją, w której o sposobie i stopniu odseparowania decydują jej członkowie. Niezależnie jednak od rodzaju izolacji dobrowolnej (morska, antarktyczna, kosmiczna) lub przymusowej (szpitalna, więzienna, obozowa) ${ }^{6}$, mimo rozmaitych środowisk izolujących, ich zróżnicowania strukturalnego i funkcjonalnego, można wskazać pewne cechy wspólne, które opisują problem izolacji, co podkreśla w swoich pracach wielu badaczy zajmujących się tą tematyką, między innymi Mieczysław Ciosek, piszący o izolacji w kontekście więzienia ${ }^{7}$, czy Mieczysław Plopa, analizujący sytuację izolacji morskiej ${ }^{8}$.

względów instrumentalnych (koszary wojskowe, internaty, okręty, łodzie podwodne). Ostatnia grupa to instytucje, w których uczestnictwo jest dobrowolne, a sens ich istnienia sprowadza się do realizacji wartości religijnych, duchowych (klasztory). Zob. E. Goffman, Charakterystyka instytucji totalnych, tłum. Z. Zwoliński, w: Elementy teorii socjologicznych, red.W. Derczyński, A. Jasińska-Kania, J. Szacki, Warszawa 1975, s. 87.

5 N. Klein, No logo, s. 205.

6 Ze względu na właściwości środowisk (instytucji) izolowanych Adam Podgórecki zastosował następujące kryteria podziału: motywacja jednostki, która ma wejść do instytucji zamkniętej, społeczna ocena celu jednostki, miejsce położenia, przyczyna wyizolowania danej społeczności. Ostatnie wymienione przez badacza kryterium pozwala na wyróżnienie dwóch typów wyizolowania danej społeczności: wyizolowanie jako rezultat instytucjonalnego zorganizowania tej społeczności (szpitale, więzienia, statki) oraz instytucjonalne wyizolowanie się danej społeczności powstałe na skutek innych apriorycznych czynników (tajne stowarzyszenie).Zob. A. Podgórecki, Spoteczności wyizolowane, w: Zagadnienie marginesu spotecznego a sprawiedliwość, red. B. Hołyst, Warszawa 1977.

7 M. Ciosek, Izolacja więzienna. Wybrane aspekty izolacji więziennej w percepcji więźniów i personelu, Gdańsk 1993; idem, Cztowiek w obliczu izolacji więziennej, Gdańsk 1996.

8 M. Plopa, Stres w izolacji morskiej. Psychospoteczne uwarunkowania, Gdańsk 1996; idem, Poczu- 
Te rozważania dotyczące izolacji w firmie nie pretendują do eksplikacji nowej teorii, jednak pozwalają przyjrzeć się zagadnieniu izolacji zarówno w wymiarze przestrzennym (przestrzeń izolowana), międzyludzkim (rozmowy izolowane), jak i personalnym (ucieczka $z$ izolacji). Fenomen ten można zatem potraktować jako stały punkt odniesienia dla charakterystyki organizacji i analizy ludzkich zachowań. Inspiracją do podjęcia tego tematu stało się malarstwo Edwarda Hoppera, a szczególnie obraz olejny Nocne ćmy z 1942 roku (Nighthawks, inne polskie wersje tytułu: Nocne marki, Nocni wtóczędzy), dzięki któremu (zapewne nieświadomie) artyście udało się przedstawić fenomen szklanej izolacji. Problem izolacji w firmie został omówiony na podstawie analizy dwóch sztuk dramatycznych: Top Dogs Ursa Widmera i Po deszczu Sergiego Belbela. Natomiast pojęcie izolacji można zdefiniować za Mieczysławem Cioskiem jako „układ relacji, który zachodzi pomiędzy człowiekiem a otoczeniem w jakiś określony sposób zamkniętym”.

\section{Przestrzeń izolowana}

Izolacja przestrzenna może wynikać z ukształtowania struktury miejsko-architektonicznej i interpersonalnej, czyli z różnych układów społeczno-hierarchicznych. Sama przestrzeń pełni wiele funkcji w percepcji poszczególnych grup i jednostek, które jej doświadczają. Przestrzeń najbliższa, codzienna: miasto - budynek miejsce pracy, to często zamknięty świat oddzielony granicą, murem, szybą. Współczesność z tej perspektywy jawi się jako przeszkoda dla człowieka, jego zewnętrzne ograniczenie czy też blokada dla jego przeżyć.

Dominujące we wszystkich miastach świata „wieże sukcesu”, wieżowce sięgające chmur i „katedry kapitalizmu” pozostały nadal architektonicznym ucieleśnieniem sztuki i biznesu na wysokościach. Budynki ze stali i szkła, z betonu i aluminium zawsze fascynowały artystów. Już w pierwszej połowie XX wieku Edward Hopper zwrócił uwagę na ich tajemniczość (lustrzane odbicia, migotliwość świateł, zaciemnienie) i niebezpieczeństwo (samotność, osaczenie, depresja).

Nocne ćmy, scena miejska namalowana przez Hoppera w 1942 roku, to jedyny jego obraz, który przedstawia wygiętą szybę, dzięki czemu można dostrzec szkło. Oszklona restauracja, czy może raczej bar, stanowi zamkniętą przestrzeń, oddzielając klientów od miasta. Artysta pokazuje w ten sposób relację między zewnętrznym a wewnętrznym, między przestrzenią otwartą a zamkniętą. Cztery postaci,

cie osamotnienia w izolacji morskiej. Uwarunkowania rodzinne, „Przegląd Psychologiczny” 1996, nr 3/4.

9 M. Ciosek, Cztowiek w obliczu izolacji więziennej, s. 234. 
izolowane od ulicy witryną, wydają się zamknięte w barze niczym w lekko podświetlonym akwarium. Jest to, jak na ujęcie Hoppera malującego najczęściej samotne postaci, scena niemal zbiorowa. Nie chodzi tutaj o iluzyjne odbicie pozascenicznej rzeczywistości ani o przedstawienie gotowej sceny, ale o ukazanie ludzkiego istnienia uwikłanego - jak stwierdza amerykański socjolog Richard Sennett - w „paradoksie przezroczystej izolacji” ${ }^{\text {Io }}$. W zaprojektowanej przez Hoppera scenie-obrazie Nocne ćmy ważna jest przestrzenna granica nie tylko między przeszklonym barem a ulicą, lecz także między klientami a barmanem oraz między kobietą a mężczyznami. Tę granicę podkreślają ściana ze szkła i dwa rekwizyty: kontuar oraz papieros w dłoni mężczyzny.

Artystyczna koncepcja Hoppera może się pokrywać z socjologiczną teorią Goffmana $^{\text {II }}$. Socjolog wiąże pojęcie izolacji z funkcjonowaniem instytucji zamkniętych, totalnych (closed institutions), które utrudniają lub uniemożliwiają człowiekowi kontakt ze światem zewnętrznym. Zwraca też uwagę na to, że czynnik „instytucjonalności” prowadzi do zatarcia różnic między życiem publicznym a prywatnym. Cała aktywność jednostki przebiega na oczach innych i w rytmie narzuconym przez regulamin. Stały motyw szyby na obrazach Hoppera uświadamia odbiorcy, że podgląda prywatne i publiczne życie jednostki. Na tym polega paradoks szklanej izolacji - szkło oddziela od świata zewnętrznego, ale ze względu na fizyczne właściwości (przezroczystość) umożliwia jego widzenie (kontakt wzrokowy). Ten typ izolacji można zatem wiązać $\mathrm{z}$ takimi instytucjami, których siedziby mieszczą się w szklanych budynkach (na przykład banki, firmy, korporacje, towarzystwa ubezpieczeniowe w wieżowcach ze szkła, aluminium, stali). Obecnie - poza zastosowaniem lustra weneckiego zamiast klasycznej szyby - pojawia się również tendencja do zasłaniania okien. Architekt, urbanista, architekt wnętrz i projektant mebli Stanisław Fiszer w wywiadzie udzielonym dla miesięcznika „Odra” powiedział: „A właśnie za chwilę mam spotkanie z użytkownikiem tego nowego budynku w Alejach Ujazdowskich w sprawie zasłon, bo ci, którzy tam pracują, nie chcą być

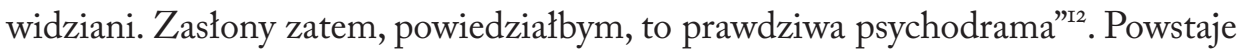
więc efekt podwojenia szklanej izolacji - przez zasłonę. Tego typu rozwiązanie budzi skojarzenia ze sceną (jawne miejsce spotkań z klientem) i kurtyną (ukryte miejsce przygotowań).

Miejscem akcji dramatu Sergiego Belbela ${ }^{\mathrm{I3}}$ Po deszczu to „Taras na dachu czter-

10 R. Sennett, Ciato i kamień. Człowiek i miasto w cywilizacji Zachodu, tłum. M. Konikowska, Gdańsk 1996, s. 18.

11 E. Goffman, Charakterystyka instytucji totalnych, s. 87.

12 Gra z przechodniem. Ze Stanistawem Fiszerem rozmawia Marta Leśniakowska, „Odra” 2003, nr 7/8, s. 81.

13 Sergi Belbel (ur. 29 maja 1963 r.) - kataloński dramatopisarz, tłumacz, reżyser i scenarzysta. Do 
dziestodziewięciopiętrowego wieżowca, w którym mieszczą się biura o wysokim standardzie"I4. Prawdopodobnie jest to strzelista konstrukcja ze stali, betonu i szkła, funkcjonalna przestrzeń o imponującej wysokości i bezpiecznej konstrukcji. Cały personel (Komputerowiec, Kierownik, Dyrektorka, Goniec, sekretarki: Blondynka, Brunetka, Ruda, Szatynka) w czasie godzin pracy marzy właściwie o jednym ukradkowym wyjściu na taras wieżowca, aby zaczerpnąć świeżego powietrza lub zapalić papierosa. Można za Goffmanem przyjąć, że pojawia się tutaj podział na scenę (miejsce wystąpień pracowników firmy - kwestie wyuczone) i kulisy (spotkania na tarasie - rozmowy garderobiane). Dopiero „za kulisami ujawnia się istotne tajemnice przedstawienia i skoro wykonawcy wychodzą tutaj z roli, jest rzeczą naturalną, że miejsce to jest niedostępne dla publiczności i że nawet ukrywa się przed nią jego istnienie" ${ }^{\prime 5}$. Mimo iż w całym budynku obowiązuje zakaz palenia, ów nieformalny, codzienny rytuał spotkań przy papierosie z jednej strony oddziela pracowników od wnętrza firmy, $z$ drugiej zaś służy spotkaniu $z$ drugim człowiekiem na zewnątrz budynku. Na gruncie jednej organizacji powstaje następna organizacja nieformalna - zrzeszająca palaczy. Ich cel to codzienny rytuał wejścia bądź wjazdu na taras wieżowca i zapalenie papierosa. Wszyscy należą do tej nieformalnej, podziemnej (a może raczej tarasowej?) organizacji: Kierownik („gdybym nie mógł palić, to bym zwariował”), Kierowniczka („szefowa nie odważy się zwrócić mi uwagi, ona też pali”), Komputerowiec („Zapala. [...] Dziękuję. Tak, te są drogie”), sekretarki Ruda, Blondynka, Brunetka, Szatynka (,Wszystkie cztery zapalaja jednoczesnie papierosy wtasnymi zapalniczkami. Pala"). Grupa nieformalna ze sztuki Belbela Po deszczu jest grupą uzależnioną. Jednak palenie stało się głównym czynnikiem sprzyjającym w procesie centralizacji grupy. Oczywiście, jak każdy nałóg, nikotynizm wiąże się z uczuciem nienasycenia w sferze emocjonalnej. Odkrywamy zatem problem wszystkich członków organizacji, jaki usiłują może nie tyle rozwiązać, ile zredukować. Rytuał palenia staje się podstawową formą zachowań, zapewniającą kontakt z drugim człowiekiem.

Taras na dachu wieżowca i winda dla personelu firmy to miejsca służące przypadkowym spotkaniom, na które składają się: wyminięcia, otarcia, przepchnięcia,

ważniejszych jego utworów dramatycznych należą: Caleidoscopios y faros de hoy (1986), Minim-mal show (1987), Elsa Schneider (1987), Ópera (1988), En companyia d’abisme (1988), Tálem (1989), Carícies (1991), Després de la pluja (1993), Morir o no (1994), La boca cerrada (1996), La sang (1998) czy musical El temps de Planck (2000). Belbel jest zaliczany do najwybitniejszych twórców współczesnego teatru hiszpańskiego, a także europejskiego, należy do pokolenia pisarzy z kręgu „brutalistów”. Stylizowany język i dramatyczna struktura jego utworów, odbiegających od realistycznych czy symbolicznych konwencji, dążą do ukazywania prawdy o ludzkiej codzienności. Zob. https://encyklopediateatru.pl/autorzy/2761/sergi-belbel (stan z 21 grudnia 2021 r.).

14 S. Belbel, Po deszczu, tłum. M. Mętrak-Gottesman, „Dialog” 1999, nr 4, s. 25.

15 E. Goffman, Człowiek w teatrze życia codziennego, tlum. H. Datner-Śpiewak, P. Śpiewak, Warszawa 2000, s. 142. 
przeciśnięcia tych z jednej i tamtych z drugiej strony. W uchylonych drzwiach windy, w korytarzach wielkiej korporacji pojawia się silne pragnienie bohaterów, aby w jakiś sposób rozjaśnić szarą i banalną codzienność. Taras na dachu wieżowca uzmysławia dwie sytuacje egzystencji człowieka, a więc graniczność (przestrzeń otwarta, ponad firmą - wolna; przestrzeń zamknięta - zniewolenie w firmie) oraz stan zawieszenia (między miastem a piętrami biura, wyborem palenia a poddaniem regulaminowi). Każde wejście na taras pozwala postaciom dramatu dotknąć nieba (obserwują ołowiane niebo przed burzą, niebo w ogniu burzy i niebo z promieniami słońca po deszczu) i doświadczyć piekła ulicy (widzą roztrzaskany helikopter, słyszą trzask tłuczonego szkła, wezwania o pomoc, syreny). To, co oglądają bohaterowie, wiąże się z pojęciem bezkresu, nieskończoności (niebo) i scentralizowania, skończoności (obszar miasta). Niezależnie jednak od dostrzegalnej, przeżywanej sytuacji palą papierosy i często opierają się o barierę.

Lokalizacja tarasu przypomina o podwójnej granicy: pojawia się bariera między budynkiem a pozostałą częścią miasta-świata oraz granica w postaci zasłony z dymu między ludźmi i ich wewnętrznym światem.

\section{\Scena $2[\ldots]$ \\ Brunetka podchodzi do bariery, potyka się i traci równowagę. Blondynka i Ruda, przestraszone, krzyczq histerycznie. Szatynka przytrzymuje za ramię Brunetkę, która w potowie zawieszona jest w przestrzeni. Pomaga jej się pozbierać. Napięcie. \\ Szatynka Dlaczego to zrobiłaś? \\ Brunetka Przecież nic nie zrobiłam. \\ Szatynka Dlaczego to zrobiłaś? \\ Brunetka Tylko się poślizgnęłam. \\ Blondynka Wariatka, nie znoszę takich żartów. O mało nie dostałam zawału serca! \\ Ruda (do Blondynki) Już nie wie, co ma wymyślić, żeby zwrócić na siebie uwagę, nie znoszę jej, po prostu nie znoszę! ${ }^{16}$}

Granica zawsze wiąże się z przekroczeniem, z pokusą przejścia na drugą stronę. Stan zawieszenia jest wyjątkowo trudny, łączy się z poczuciem bycia w potrzasku, a nawet uwięzienia. Jedynie Brunetka w sposób mniej lub bardziej przemyślany usiłuje przerwać linię ograniczenia, gdyż pochylając się nad barierą, widzi fascynującą, rozległą i jasną perspektywę pulsującego miasta. Urzeka ją to, co znajduje 
się nad i pod budynkiem, rozległa wolna przestrzeń, w której można nabrać kojącego oddechu. Jednak z przekroczeniem nierozerwalnie wiąże się pewne ryzyko.

W dramacie Po deszczu przekroczenie połowiczne (Brunetka przy barierce) można łączyć $z$ jasnością i ruchem, natomiast całkowite $-z$ ciemnością i bezruchem (wypadek Kierownika). Sztuka Belbela ukazuje specyficzny efekt „izolacji w izolacji”. W izolowanej przestrzeni organizacji pracownicy tworzą następną - na tarasie, łączącym się z wyobrażeniem o romantycznych scenach balkonowych. Istotnie, dopiero za zasłona z papierosowego dymu postacie prowadzą rozmowy, w których odsłaniają swoje uczucia, frustracje, pragnienia i lęki.

Utwór Belbela pokazuje rozmaite kombinacje gry o przestrzeń, co jest podyktowane próbą wyjścia pracowników poza ustalone schematy firmy, ale w sztuce Ursa Widmera ${ }^{\text {I7 }}$ Top Dogs przestrzeń organizacji jest czymś tak fascynującym, że zaczyna wchłaniać postacie. Budynek firmy przypomina wielopiętrową izolatkę, a wszyscy pracownicy zostali zamknięci w „szklanej pułapce” marzeń o sukcesie. Nawet wówczas gdy tracą swoje posady - nie potrafią się z niej wydostać.

Bohaterowie sztuki Top Dogs całkowicie utożsamiają się z firmą, w której pracują. Ich życie zostaje zredukowane do jednej sfery - pracy, co w konsekwencji prowadzi do utraty wrażliwości na otaczający świat i do poczucia bezgranicznej pustki. Nawet marzenia bohaterów Top Dogs zostają zawężone do granic strzelistych konstrukcji - biurowy wieżowiec staje się ikoną sukcesu i upragnionym domem.

\section{\Jenkins $[\ldots]$ gabinet cały ze szkła. Najwyższe piętro. Wyjście na taras. Przed nim panorama drapaczy chmur. W dole Park Centralny. Rozumie się, że mój gabinet jest w Nowym Jorku. Nosi moje imię, cały budynek. Jenkins-Bulding. Mieści moje wszystkie przedsiębior- stwa. The Julika-Corporation [...] Jenkins International ${ }^{18}$.}

Związek osoby z przestrzenią zacieśnia się do takiego stopnia, że można powtórzyć za Piotrem Bratkowskim - „ja to frma” "I9. Ponadto zanika podział na scenę (dla klientów) i kulisy (dla personelu) na powierzchni dyrektorskiego apartamentu. Jak zauważa Goffman:

17 Urs Widmer (ur. 21 maja 1938 r.-zm. 2 kwietnia 2014 r.) - szwajcarski pisarz i tłumacz, piszący w języku niemieckim. Autor opowiadań Alois (1968), dramatów Dtuga noc detektywów (1973), Wszystko gra (1987).W 1996 r. opublikował sztukę Top Dogs, której prapremiera odbyła się w Theater Neumarkt w Zurychu. Została ona uznana za najlepszy dramat niemieckojęzyczny sezonu 1996/1997. Widmer otrzymał za nią nagrodę stacji telewizyjnej 3SAT. Zob. https://encyklopediateatru.p1/autorzy/2534/urs-widmer ( $\operatorname{stan}$ z 21 grudnia 2021 r.).

18 U. Widmer, Top Dogs, tłum. J. Koenig, „Dialog” 1998, nr 8, s. 78.

19 P. Bratkowski, Ja, firma, „Dialog” 1998, nr 8, s. 87. 
\ Tak więc gabinet kierownika jest oczywiście sceną, na której pokazuje się jego pozycję w hierarchii za pomocą mebli i dywanów. Jednocześnie kierownik może w tym samym miejscu zdjąć marynarkę, rozluźnić krawat i trzymać w ręku butelkę, zachowując się przyjacielsko czy wręcz swobodnie wobec kolegów o tej samej pozycji ${ }^{20}$.

W tym momencie pojawia się zasadniczy problem $\mathrm{w}$ traktowaniu przestrzeni szklanego biurowca. Nie jest to tylko miejsce pracy, ale też nie jest to „miejsce zamieszkania”, „miejsce pobytu” ani zwyczajny „dach nad głową”2I. Długość czasu, który spędzają pracownicy firmy w wielopiętrowym wieżowcu, pozwala określić ich pobyt jako sytuację zamieszkania. Ich samotność jest bliska doświadczeniu bezdomności. Zamieszkać, to inaczej zatrzymać się po to, by wybranemu miejscu nadać sens, by ów fragment otaczającej przestrzeni wyrwać z anonimowości, uczynić znanym i nazwanym. Taki punkt na mapie miasta przekształca się w przestrzeń oswojoną („mój gabinet”), nazwaną („budynek Jenkins-Bulding”) i zasiedloną („wszystkie moje przedsiębiorstwa, Jenkins International”).

Bohaterowie czują się uwięzieni na swoich stanowiskach, przywiązani do miękkich foteli i niemalże „przyklejeni” do widoku z okna gabinetu. Właściwie problem postaci Top Dogs nie sprowadza się to tego, że któregoś dnia, wchodząc do dobrze znanego budynku, zupełnie nieoczekiwanie stracili posady. Kłopot polega na tym, że po wyjściu ze szklanego wieżowca nie mają do czego i do kogo wrócić. Powrót do domu - jedna z najstarszych figur naszej kultury - okazuje się nie tylko dwuznaczny, ale coraz częściej wręcz nieosiągalny. Idea powrotu do domu traci sens wtedy, gdy znajduje się on wszędzie, czyli - trawestując Alfreda Jarry'ego - nigdzie. Korporacja jest organizacją totalną ${ }^{22}$. Wymaga od pracowników całkowitego oddania, burzy granicę między tym, co prywatne, osobiste, intymne, a tym, co publiczne, zawodowe i jawne.

W sztukach Ursa Widmera i Sergiego Belbela przestrzeń wielopiętrowych budynków firm wchłania (Top Dogs) i pochłania (Po deszczu) człowieka. To, co w sensie zewnętrznym reprezentują bohaterowie, obserwujemy - paradoksalnie - wewnątrz biurowca (ubrania, fryzury, służbowe konwenanse, etyka zawodowa), a całe ich wnętrze zostaje odsłonięte na zewnątrz budynku (lęk i frustracja, zagubienie i samotność). „Wiele zachowań, jakie przejawiają ludzie izolowani - stwierdza Mieczysław Ciosek - ma charakter reakcji obronnych przed stresem środowiska

20 E. Goffman, Cztowiek w teatrze życia codziennego, s. 154.

21 Zob. E. Rewers, Środowisko rozmowy, w: Pamięć, miejsce, obecność. Wspótczesne refleksje nad kultura i ich implikacje pedagogiczne, red. J. Hudzik, J. Mizińska, Lublin 1997, s. 106.

22 P. Bratkowski, Ja, frma, s. 90. 
zamkniętego” ${ }^{23}$. A zatem można przyjąć, że efekt „izolacja w izolacji” jest dążeniem do zachowania własnej przestrzeni, w której dopuszczalne są swobodne zachowania i niczym nieskrępowane wypowiedzi.

Personel firmy w sztukach Top Dogs i Po deszczu to osoby funkcjonujące w grupie, które na planie akcji dramatu istnieją jednak osobno. Ich samotność podkreśla brak języka komunikacji interpersonalnej i społecznej. Działają wspólnie w przestrzeni wielu pięter, ale w rzeczywistości żyją obok siebie. W procesie nadmiernego zagęszczenia i codziennej bliskości pojawia się potrzeba odosobnienia - izolacji - w celu zachowania ramy dla swojej tożsamości. Co więcej, chociaż izolacja jest sytuacją trudną, związaną z długotrwałym stresem i napięciem lękowym, ma także pozytywny wydźwięk, mianowicie pozwala ocalić granice własnej, indywidualnej przestrzeni.

\section{RozMOWY IZOLOWANE}

Przestrzeń izolowana staje się warunkiem do funkcjonowania różnego typu kodów komunikacji, a szczególnie komunikacji językowej. Istotą tej komunikacji jest szeroko pojęty dialog - rozmowa, która jest wymianą zrozumiałych dla nadawcy i odbiorcy słów oraz treści. Rozmowa izolowana odbywa się natomiast w wyznaczonym do tego celu miejscu, a jej treść jest nieznana (ukryta) dla jednego z rozmówców. Zawiera jednak ze względu na ukryty charakter treści duży ładunek emocji, cechują ją szczerość i dosadność wypowiedzi.

We współczesnym świecie obserwuje się zjawisko autonomizacji słowa, które uwikłane w niekończące się sieci powiązań intertekstualnych, odsyłających zawsze do kolejnych słów, zatraciły potrzebę referencji i związek ze światem pozajęzykowym. W efekcie, ponieważ język - wedle tych samych teorii - jest jedynym narzędziem wyrażania myśli: „Świat (myśli) znajduje się (teraz) wewnątrz słowa” ${ }^{24}$. To oderwanie słów od rzeczywistości pozajęzykowej (a więc świata desygnatów zarówno materialnych, duchowych, emocjonalnych, jak i intelektualnych) ma swą bezpośrednią przyczynę w dewaluacji tej rzeczywistości. Słowa pozbawione stałych punktów odniesienia w świecie wartości i czytelnych znaczeń odsyłają jedynie do innych słów. Krążą wyłącznie w „obiegu zamkniętym” - stają się słowami izolowanymi. Dotyczy to nie tylko słów o zamkniętym obiegu znaczeń (terminologia specjalistyczna grupy zawodowej), ale również wyrazów „Zamkniętych” w rozmowach nacechowanych emocjonalnie (kolokwializmy środowiskowe). Język ma 
zatem wpływ na budowanie szeroko pojętych więzi międzyludzkich, wpływa także na kształtowanie więzi w organizacji.

Do budowania tych relacji jest potrzebny określony język, który służy porozumieniu i sprzyja realizacji zadań. Komunikację uznajemy za dobrze przebiegającą, jeżeli tekst okaże się zrozumiały dla odbiorcy we wszelkich funkcjach, jakie nadaje mu nadawca. Niezrozumiałość to główny przejaw zakłóceń w aktach porozumiewania się za pomocą języka naturalnego. Może ona być spowodowana bardzo wieloma czynnikami - dotyczyć formy komunikatu (układu zdania i sposobu jego wypowiedzenia), nieznajomości znaczeń wyrazów (ze strony nadawców tekstu czy też ich odbiorców), a także wynikać z wartościujących konotacji wyrazów (nacechowanie emocjonalne), błędnego odczytywania znaczeń intencjonalnych (nieporozumienia oparte na wieloznaczności słów). Można uważać, że 'dzielenie się czymś z kimś', które leży u podstaw łacińskiego czasownika communicare, ma być w przypadku mowy dzieleniem się swoimi myślami, uczuciami, aktami woli - a to właśnie ono w komunikacji językowej sprawia poszczególnym stronom najwięcej trudności. Coraz częściej rozmówcy stają się aktorami w maskach, te zaś bynajmniej nie służą do celów ludycznych, lecz zazwyczaj do tego, by w jakiś sposób dominować nad innymi, kierować ich zachowaniami, ukrywając swoje cele i słabości. Świat wewnętrzny każdego człowieka jest miejscem, w którym dochodzi do nieustannej analizy własnego języka w relacji do czyjejś wypowiedzi.

Aby lepiej przyjrzeć się istocie tego problemu, warto odwołać się do kilku scen zawartych w sztukach Top Dogs i Po deszczu. Język bowiem łączy się ze stanem poczucia obcości między jednym a drugim człowiekiem, co zostaje uwydatnione w dialogach postaci z Top Dogs Widmera.

\section{》On Rozmawiam $\mathrm{z}$ tobą $[\ldots]$}

Ona [...] On nigdy nie słucha, i zawsze mówi do mnie „myszko”. Nie znoszę tego "myszko”. (do męża, jako Ona) Myszko. (znowu jako jej mą்̇) Twoje zajęcia domowe to jeszcze nie cały świat. W biurze chodzi o sumy rzędu pięciuset tysięcy, a może nawet ośmiuset tysięcy franków. A ta filiżanka, myszko, jak ją rozbijesz, ile jest warta? Pięć osiemdziesiąt. Zresztą tak naprawdę - nie ma żadnej wartości katalogowej. No, dodajmy jeszcze tu płyn do zmywania, którego używasz w zmywarce dla jej obsługi. Wartość bliska zeru. Ile więc warte jest to całe gospodarstwo domowe? [...] O czym my w ogóle rozmawiamy? Ja mam na biurku transakcje milionowej wartości, a ty mi zawracasz głowę filiżankami po kawie. 
On Wiem, nigdy nie umiem słuchać, kiedy chcesz mi coś wyjaśnić $[\ldots]^{25}$.

Język porozumienia między małżonkami jest pozorem mówienia, zdolnym rzeczywiście uczynić rozmowę wymianą pustych zdań. Między małżonkami powstaje przestrzeń obcości, trudno im bowiem odnaleźć wyjście z kłopotliwej sytuacji. On czuje się niepotrzebny, gdyż stracił intratną posadę, a Ona nie wie, jak mu pomóc. W przytoczonym fragmencie przestrzeń zostaje zapełniona słowami układanymi gęsto, tuż obok siebie, bez perspektywy i hierarchii. Wzorowana na rozmowie kompozycja dialogu - wbrew prostocie i banalności tekstu - ujawnia istnienie czegoś wyższego rzędu: przestrzeni pełnego słowa. Można mówić o małych rzeczach (filiżanka, biurko), aby tym samym rozmawiać o rzeczach znaczących (cały świat to jej gospodarstwo domowe, jego praca w firmie).

Zubożenie języka, a wraz z nim ograniczenie świata wiążą się w tej sztuce $\mathrm{z}$ redukcją aktywności życiowej poszczególnych osób. Każda z postaci żyje w swoim świecie i posługuje się stosownym do niego językiem. Mamy zatem zobrazowanie rozmowy izolowanej, która rozpada się na dwa kręgi semantyczne wyrażeń: dialogi dotyczące domu i domowych czynności oraz wymiany zdań związane z miejscem pracy i wykonywaniem finansowych operacji. Rozmowa izolowana powstaje w wyniku braku dostosowania odpowiednich słów i wyrażeń właściwych w danym miejscu i określonej sytuacji - tak oto w domu mówi się jak w firmie. Urwane, niedokończone zdania, dręczące, trafiające w próżnię zapytania wiodą do porażenia języka. Tak silne zakłócenie prowadzi do pozornych spotkań, powierzchownych kontaktów, stopniowego zaniku więzi międzyludzkich. Jeżeli rozmowa istnieje nie po to, by uzyskać sens, szukać go i nań natrafiać, wówczas przestaje być komunikatem, a staje się „komunikatem”, nie tyle czystym środkiem porozumienia, ile bezcelowym środkiem nieporozumienia.

W kontekście rozważań o rozmowach izolowanych warto powrócić do scen ze sztuki Top Dogs. W części zatytułowanej 8. Marzenia jeden z jej bohaterów, Krause, wyznaje:

\Kiedy tkwisz po uszy w robocie, jesteś tak zaabsorbowany osiągnięciem własnego celu, że nie masz czasu dla ludzi, którzy obsługują twoje maszyny. W trakcie procesu pracy zapomina się o tym, że za każdym zadaniem kryje się człowiek ${ }^{26}$.

25 U.Widmer, Top Dogs, s. 74.

26 Ibidem, s. 76. 
Pewnym nadużyciem, ale w tym miejscu uzasadnionym, będzie przypomnienie najbardziej znanej tezy z Traktatu logiczno-filozoficznego Ludwiga Wittgensteina, że granice naszego języka oznaczają granice naszego świata. Myśl tę można rozważać jako odniesienie do zaniku świata ludzkiego życia i jego wytworów, będącego skutkiem zubożenia komunikacji. Chodzi więc o język jako podstawowe medium oraz o postępującą nieistotność komunikatów. Wiele z nich charakteryzuje się swoistą beztreściowością. Język pracowników w Top Dogs jest równie wąsko wyspecjalizowany jak zawody, które uprawiają - potrafią myśleć wyłącznie kategoriami pracy i kariery.

W sztuce Po deszczu prowadzone przez personel na tarasie wieżowca rozmowy w odróżnieniu od tych oficjalnych (jawne, grzecznościowe, staranne, wyspecjalizowane) - przypominają natomiast dialogi izolowane (ukryte, wulgarne, chaotyczne, potoczne).

\section{\Scena 2}

Brunetka Nie rozumiem.

Blondynka A propos, skoro już przy tym jesteśmy: która wjeżdżała wtedy windą? Któraś z was, dziewczyny, bo mówił mi ten pedał, to znaczy windziarz, jadę sobie jakby nigdy nic, a on do mnie: nie uważasz skarbie, że coś tu śmierdzi? Co śmierdzi? - mówię. No właśnie kiciu, okropnie śmierdzi papierosami [...].

Scena 5

Kierownik To o co chciała mnie pani spytać?

Blondynka Hmm... no nie wiem.

Kierownik Więc o co?

Blondynka Nie wiem, czy będę miała odwagę, żeby... Ale ponieważ jesteśmy tutaj, poza biurem i w ogóle... no dobrze, dlaczego pan to zrobił?

Kierownik Co?

Blondynka No, chodzi o sukienkę. [...]

Kierownik $Z$ powodów osobistych.

Blondynka Przepraszam, nie rozumiem pana.

Kierownik Nie musi pani nic rozumieć.

Blondynka Jak to nie? Co pan właściwie mówi. Powiem panu szczerze... Prezent... prezent [...] cha cha cha, no nic, myślę, że musi być jakiś związek bardziej, no troszkę bardziej, jakby to powiedzieć, no bardziej bliski, prawda? [...]

Scena 6

Brunetka Kłamliwa kurwa, obrzydliwa zazdrośnica, a więc właśnie 
wychodziłaś, co? Zazdrosna świnio, nie spuszczałaś z nas oczu, cały czas się gapiłaś, a przedtem mówiłaś, że on ci się nie podoba, powiedziałaś nie znoszę tego faceta, a teraz pożerałaś go wzrokiem, tchórz kłamliwy [...] oszustko, prymitywie, ezoteryczna cholerna małpo! ${ }^{27}$

Szablony językowe, epitety, inwektywy. Walka o stanowisko wyzwala emocje, przy czym zwykle są to emocje negatywne. Poziom języka wyznaczają oskarżycielski ton, insynuacje, pomówienia. Taki emocjonalny dialog, ocierający się nawet o brutalność, jest właściwie rzeczą naturalną, gdy chodzi o zdobycie określonej pozycji za wszelką cenę. Język funkcjonuje tu na rozmaitych stopniach organizacji i w różnych przejawach, ze szczególnym uwzględnieniem jego żywej formy, czyli "gadania". Pisanie o gadaniu jest bliskie jemu samemu - wszak tutaj też "gadają" poszczególne postaci. Wszyscy pracownicy firmy "gadają" na tarasie, paląc papierosy. $Z$ tego mówienia wynika znacznie więcej, niż można by się spodziewać po języku traktowanym jako narzędzie komunikacji. Aby zaistnieć w świecie, trzeba nie tylko mówić, ale również „być mówionym”. Mówienie jest tożsame z istnieniem, bowiem nawet jeśli jest ono prozaicznym gadaniem, to i tak służy podtrzymaniu więzi nieformalnej organizacji. Warto dodać, że te „zakulisowe” rozmowy na tarasie wieżowca sprzyjają także podejmowaniu decyzji i ustaleniu oficjalnych rozwiązań, choć w sposób nieoficjalny (tak zwane rozmowy pokątne, za plecami).

\section{\Scena 7 \\ Dyrektorka Tutaj nikt nie będzie nas słyszał [...]. Co? Nie wjecha- liśmy tutaj, żeby... palić. [...] \\ Szatynka Czuję się trochę niezręcznie. [...] \\ Dyrektorka Pozwolisz, że będę mówiła dalej? Dziękuję. Świetnie. Nie wiem, czy nie zdziwi to pani, co chcemy zaproponować. No więc, chodzi o... [...]}

Kierownik Dobrze... Wybraliśmy panią w drodze eliminacji. Jeżeli chodzi o sekretarki z naszej firmy, to wybór jest dość ograniczony $[\ldots]^{28}$.

Rozmówcy, którzy nie dostrzegają wyraźnie podmiotu więzi, jednak w toku komunikacji do niego zmierzają. Mogą zatem przedstawić swoje intencje w postaci „płaszczyzn”, które dodając, a raczej składając się w toku komunikacji, tworzą addytywną formę intencji wielowymiarowej, a jednocześnie scalonej równopraw- 
nymi intencjami rozmówców. Tak więc modelowo ilustrując przedmiot więzi, intencje rozmówców dadzą się wyobrazić w postaci wielopłaszczyznowej bryły, którą każdy buduje ze swej strony, a poznaje $\mathrm{z}$ różnych stron.

W innym modelu rozmowy izolowanej chodzi o intencje, które „są w słowach”, a nie „kryją się pod słowami”. Właśnie intencje, bardziej niż słowa, ulegają tu wymianie i poznaniu. Model ten ponad „grę słów”, do której zmuszają nas nakazy języka, preferuje ,grę intencji”.

\section{\Scena 7}

Szatynka Przypuszczam, że nie odejdą państwo z firmy, dopóki nie załatwią wszystkiego, co ma związek z tą nową firmą?

Dyrektorka Oczywiście.

Szatynka To może potrwać miesiące.

Dyrektorka Wszystko jest przewidziane: szesnaście miesięcy. [...]

Szatynka I będziecie to państwo trzymać w tajemnicy przez szesnaście miesięcy?

Dyrektorka Oczywiście. [...]

Szatynka Nie powiem. Ale nie zamierzam brać udziału w waszym okropnym projekcie. [...]

Dyrektorka Niech pani posłucha, my chcemy czegoś nowego, małego, samodzielnego, twórczego, w gruncie rzeczy to ambitny projekt, niech się pani zastanowi, nie podoba nam się sposób, w jaki prowadzi się tu interesy, tutaj wszystko jest nadęte, bezosobowe, szare, rutynowe, a my szukamy przygody, ryzyka, nadziei, pasji, nie rozumie pani? ${ }^{29}$

Powyższy fragment porusza dwa ważne problemy w zakresie prowadzenia rozmów: po pierwsze - umiejętność podejmowania decyzji, co należy i można ujawnić, po drugie - sposoby utrzymania w tajemnicy pewnych rozwiązań. Osobista szczerość i otwartość jest szansą, ale stwarza też ryzyko.

\We współczesnym życiu zawodowym tkwimy w rozdarciu między wspólpracą a konkurencją. $Z$ jednej strony stawia się nam zadanie tworzenia harmonijnie działającego zespołu, tolerowania słabości i błędów innych, ujawniania własnych słabości i błędów, podporządkowania się w razie konieczności zespołowi [...]. Z drugiej strony coraz mocniej daje znać - nawet w obrębie tego samego przedsiębiorstwa - konkurencja, która skłania do postawy przeciwnej, do współ- 
zawodnictwa, do bycia lepszym od innych. Trzeba się przebijać, specjalizować, wyrastać ponad przeciętną (czyli de facto ponad zespół) $)^{30}$.

Ponadto dialog Dyrektorki z Szatynką w sztuce Po deszczu jest nacechowany informacją dezinformującą. Teoretycznie przekazywana wiadomość wynikająca z rozmowy zawiadamia o zdarzeniach (nowy projekt organizacji, jej cele i zadania), ale jednocześnie zaciera wiedzę o zaistniałych faktach (kryzys w firmie, powody rezygnacji). W procesie informacji i dezinformacji to, co oczywiste, staje się absurdalne. W ten sposób uruchamia się walka informacyjna, która prowadzi do częściowej utraty zaufania rozmówców. Często wszystkie informacje zostają uznane za nieprawdziwe, nawet te zgodne z rzeczywistością. Wówczas powstaje „pustka informacyjna, która dla większości ludzi jest trudna do zniesienia. [...] potrzeba zaufania jakiemuś źródłu informacji wydaje się jedną z podstawowych potrzeb psychicznych człowieka" ${ }^{\mathrm{I}}$.

Rozmowy mają coraz częściej charakter transakcji zarówno w życiu zawodowym, jak i osobistym. Jeśli dodamy do tego cechy współczesnego życia: nietrwałość, niepewność i zagrożenie bezpieczeństwa, to obraz życia pokazuje kruchość relacji interpersonalnych. Rozmowa izolowana oddziela ludzi (męża i żonę, pracownika i bezrobotnego), uwidacznia ich uczucia i emocje (zagubienie i samotność, złośliwość i furię), wreszcie ukrywa fakty i decyzje (zafałszowanie kryzysu, protegowany awans). Jak stwierdza natomiast Elżbieta Sujak: „obserwowane tak częste kryzysy i zaniki więzi międzyludzkich bywają raczej skutkiem zaburzeń komunikacji aniżeli cech osobowych ich uczestników" ${ }^{2}$.

\section{UCIECZKA Z IZOLACJI}

Izolacja jest sytuacją trudną, gdyż w jej obszarze oddziaływania pojawiają się z kolei sytuacje kryzysowe i nacechowane lękiem. Taka sytuacja może powodować, że jednostka świadomie odbiera ją jako zagrożenie lub doświadcza jej skutków, niekoniecznie uświadamiając sobie ich źródło. A zatem sytuacje trudne dezorganizują aktualne działania jednostki i wywierają wpływ na jej przyszłe funkcjonowanie. Środowisko zamknięte powoduje, że znacząco zostają ograniczone lub nawet przerwane (bezpośrednio, pośrednio) relacje jednostki z otwartym środowiskiem. Dlatego

30 F. Schulz von Thun, Sztuka zarzqdzania. Psychologia komunikacji dla szefów i liderów, thum. P. Włodyga, Kraków 2004, s. 179.

31 M. Mlicki, Zagadnienia informacji i dezinformacji spotecznej, w: Sposoby istnienia. Dziatanie wobec siebie i innych, red. J. Rudniański, K. Murawski, Warszawa 1988, s. 141.

32 E. Sujak, $A B C$ psychologii komunikacji, Kraków 2006, s. 8. 
„Istotą pojęcia izolacji jest zawieszenie, znaczące ograniczenie czy też zerwanie relacji”33. Izolacja wiąże się $z$ istnieniem bariery odgradzającej od świata zewnętrznego, która zmusza jednostkę do szybkiego przystosowania się do nowych warunków. Oczywiście jest to układ sztuczny, niestabilny, toteż prędzej czy później osoba izolowana będzie dążyć do przekroczenia ograniczającej bariery. Dzieje się tak nie tylko w sytuacjach izolacji przymusowej (więzienna, szpitalna), ale także dobrowolnej (morska, kosmiczna).

Ucieczka z izolacji to świadome, choć niekoniecznie przemyślane działanie jednostki w celu przekroczenia bądź zerwania krępujących więzów ograniczenia. Ucieczka wiąże się z ryzykiem. Może przynieść zarówno pozytywne, jak i negatywne skutki. Jeśli ucieczka zostaje dokładnie zaplanowana, wówczas wzrasta prawdopodobieństwo powodzenia, natomiast jeśli jest to spontaniczna decyzja, wtedy ryzyko staje się znacznie większe i zmniejsza się szansa powodzenia. Ucieczka łączy się także z pojęciem unikania (sytuacji trudnych, kryzysowych) oraz z porzuceniem (sprawy, problemu).

W dwóch omawianych sztukach - Top Dogs i Po deszczu można potraktować u cieczkę z i zolacji jako rozwiązanie ostateczne (całkowita redukcja) i tragiczne (śmierć). Bohaterowie dramatu Ursa Widmera Top Dogs to ludzie zajmujący kierownicze stanowiska, „oficerowie” wielkich firm, którzy nieoczekiwanie zostali zwolnieni. Niektórzy sami na to zwolnienie zapracowali.

\section{\Deer [...] Przeprowadziłem generalną reorganizację w cateringu. Mogę powiedzieć, że była to moja osobista inicjatywa. W cateringu byliśmy o krok od katastrofy - połączenia liniowe kwitły, a u nas wszystko się waliło. Dziś mamy to za sobą. Zbudowaliśmy solidne podstawy, bo byliśmy bezlitośni ${ }^{34}$.}

Dodo Deer początkowo nie przyjmuje do wiadomości, że w wyniku owej reorganizacji został zwolniony. Dość powszechnie znana jest historia pewnego wielkiego koncernu amerykańskiego, w którym menedżerowie średniego szczebla zostali poproszeni o opracowanie planu oszczędnościowego dla swojej firmy. Istotnie, przygotowali go tak rzetelnie, że zgodnie $\mathrm{z}$ obliczeniami - zwolnili siebie samych. Okazuje się, że zarządzanie sytuacją kryzysową, jak piszą Ian Mitroff i Christine Pearson, „wymaga moralnej i politycznej odwagi, a także siły emocjonalnej, aby móc zmierzyć się i podjąć dyskusje na nurtujące, niepewne i niepoko- 
jące tematy"35. Etyczny wymiar zarządzania sytuacjami kryzysowymi jest ważny, obok prakseologicznych i innych aspektów tego zarządzania. Mitroff i Pearson precyzują, że celem zarządzania sytuacją kryzysową nie jest wyłącznie jak najszybszy powrót do „normalności”. Jego istotą okazuje się zmuszenie organizacji do tego, aby uświadomiła sobie moralną i społeczną odpowiedzialność wobec wewnętrznych i zewnętrznych interesariuszy, wobec społeczeństwa, a nawet wobec świata ${ }^{36}$.

W sztuce Top Dogs właśnie ci bezrobotni kierownicy spotkali się w New Challenge Company (Spółka Nowych Wyzwań). Zostali tam skierowani przez firmy, które wcześniej zwolnily ich z pracy. NCC to prowadzone przez samych bezrobotnych biura pośrednictwa pracy, połączonego jednak z grupą psychoterapeutyczną. Organizację tę stworzyli pracoholicy na odwyku, usiłujący zapełnić w swoim życiu puste miejsce po pracy. Ucieczka od takiego modelu życia staje się niemożliwa, bo wyrywając się z ciasnych ram jednej korporacji, marzą o następnej. Rezultatem staje się sytuacja błędnego koła - wyjście z jednej strefy izolowania prowadzi do kryzysu, ten zaś do kolejnego odosobnienia. Niepokojące jest to, że $\mathrm{z}$ żadnej sytuacji bohaterowie nie wyciągają istotnych wniosków, a na wiele spraw nie potrafią spojrzeć $\mathrm{z}$ dystansem. Izolacja zawęża ich przestrzeń, w której myślące po korporacyjnemu umysły ulegają mechanizacji, stając się wyłącznie ,ja” w firmie.

W następnej scenie z Top Dogs (I2. Pożegnanie) jedna z dyrektorek zostaje zwolniona $\mathrm{z}$ pracy. Jednak trudno jej w to uwierzyć, nie jest też w stanie tego zaakceptować, więc przekazuje swoim przełożonym fałszywą informację o zmianie miejsca pracy.

\section{\Wrage Pani Jenkins dziś nas opuszcza. Znalazła pracę [...]. Ciekawą. [...] Pani Jenkins zajmie się koordynacją pracy między filią i centra- lą. Powinniśmy to uczcić! [...] w imieniu nas wszystkich życzę pani wszystkiego najlepszego, na drodze do dalszej kariery ${ }^{37}$.}

W wielu firmach przygotowuje się plany działania na wypadek zaistniałych sytuacji awaryjnych lub w wyniku uwarunkowań na rynku. Objęte planem przedsięwzięcia są sprawdzane w postaci gier teoretyczno-praktycznych. Proces utożsamienia własnego ,ja” ze stanowiskiem pracy jest tak daleko posunięty, że bohaterowie Top Dogs, mimo iż utracili pracę, zachowują się tak, jakby byli nadal aktywni zawodowo. Terapia jeszcze bardziej uwidacznia ich pracoholizm - nie chcą wyjść z roli, trwają już tylko na stanowiskach pracy, niczym żołnierze na straży

35 I. Mitroff, Ch. Pearson, Zarządzanie sytuacją kryzysowa, tłum. A. Janiszewski, Warszawa 1998, s. 159.

36 Ibidem, s. 162-163.

37 U.Widmer, Top Dogs, s. 85. 
pola przegranej bitwy. Pracoholizm, jak każdy nałóg, może stanowić formę ucieczki przed życiem. Dopóki pracoholik funkcjonuje, jest w tym uzależnieniu stymulowany: zarówno przez przełożonych, jak i przez nieświadomą niebezpieczeństwa rodzinę. Niemalże każda firma, wabiąc stanowiskami czy luksusem, wymaga całkowitego poddania ze strony pracowników. Ludzie kierujący się chęcią sukcesu organizują swoją aktywność, aby szybciej doświadczyć rezultatów własnych osiągnięć. Anita Roddick, cytowana przez Naomi Klein w książce No logo, wyznaje: „stworzyłam firmę, której sukces dla mnie samej był zaskoczeniem - nie tak to sobie wyobrażałam, wcale tego nie chciałam - po to, żebym mogła stanąć na moich produktach jak na trybunie i krzyczeć o tych sprawach" ${ }^{38}$.

$\mathrm{Na}$ drodze do sukcesu pojawiają się jednak porażki, które często przekształcają się w różnego rodzaju kryzysy. W I966 roku Richard Lazarus, obserwując zachowania ludzi w wielkich korporacjach, sformułował definicję kryzysu odnoszącą się do jednej osoby lub grupy ludzi:

\section{\Kryzys zakłada, że jakaś osoba lub grupa ludzka jest przez jakiś ogra- niczony czas narażona na jakieś wymagania, którym sprostać nie potrafi, albo jest na granicy swoich możliwości radzenia sobie w sy- tuacji trudnej. [...] w kryzysie nacisk jest położony na okres życia jednostki lub grupy, w którym najsilniej działa zagrożenie i frustracja, które uniemożliwiają działanie. W tej definicji nacisk jest położony na działający bodziec (stresor), który wywołuje niekorzystne zmiany utrudniające lub uniemożliwiające adaptację $e^{39}$.}

Każda organizacja i osoba jest odpowiedzialna w mniejszym lub większym stopniu za powstałą sytuację kryzysową. Dlatego też cała jednostka-zespół-organizacja ponosi, choć w różnym zakresie, odpowiedzialność za pozytywne jej rozwiązanie. Szczególna odpowiedzialność spoczywa na liderach, na których ciąży obowiązek zarządzania sytuacją kryzysową. Wojciech Gasparski w książce Decyzje i etyka w lobbingu i biznesie twierdzi: „Podstawową cnotą lidera powinna być niewątpliwie odwaga, choć nie powinna być ona zawadiacką brawurą, lecz odwagą dojrzałą, odwagą połączoną z roztropnością godną męża stanu"40.

W sztuce Belbela Po deszczu trudno rozpoznać nie tylko przyczyny, ale też kryzys. Można traktować tę sytuację dramatyczną jako odbicie rzeczywistości - kryzys łatwiej dostrzec z jakiejś zewnętrznej perspektywy, z pewnego dystansu do

N. Klein, No logo, s. 42.

39 T. Iwanek, Kryzys i jego odmiany, Wrocław 2004, s. 11.

40 W. Gasparski, Decyzje i etyka w lobbingu i biznesie, Warszawa 2003, s. 69. 
problemów. Roberto Assagioli zakłada: „My możemy opanować i kontrolować

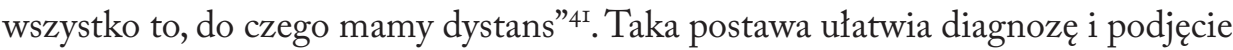
stosownych działań w celu opanowania kryzysu. Sytuacja opisywana w dramacie jest szczególnie trudna, gdyż kryzys w życiu osobistym postaci (Kierownik) nakłada się z tym zawodowym, a tak silne napięcie ulega niekiedy gwałtownemu rozładowaniu.

\author{
Scena $9[\ldots]$ \\ Dźwięk rozbijanego szkta. Szatynka patrzy w dót, przez barierę. \\ Szatynka Patrz, ktoś zbił szybę, patrz! \\ Brunetka To w moim biurze! \\ Szatynka To twój szef, patrz, wychyla się, patrz, wychodzi! \\ Brunetka Co chce zrobić? \\ Szatynka Patrzy w dół! \\ Brunetka Co robi? Czy nikt go nie zatrzyma?! \\ Szatynka Już po wszystkim. \\ Stychać przeciagty, gtęboki krzyk. Upadek. Echo. \\ Szatynka Już po nim. \\ Brunetka Rzucił się! $!^{42}$
}

O dramatycznej sytuacji zawodowej kierownika dowiadujemy się z rozmowy prowadzonej przez Blondynkę i Gońca. Sekretarka stwierdza: „wyrzucili mojego szefa, Goniec zna powody takiej decyzji, oskarżają go o wykorzystywanie wpływów, korupcję, molestowanie seksualne"43. Poszczególni bohaterowie popierają ujawnienie nieprawidłowości (whistleblowing) w funkcjonowaniu organizacji ${ }^{44}$.

Dookoła bohatera sztuki Po deszczu piętrzą się przeszkody, zostaje osaczony, zamknięty w ciasnej przestrzeni własnego gabinetu. Prawdopodobnie ma poczucie, że w tej sytuacji nie może nic zmienić, szuka więc wyjścia i znajduje - wyjście ostateczne. Jak pisze Erwin Ringel: „w momencie samobójstwa człowiek jest cał-

41 F. Schulz von Thun, Sztuka rozmawiania. Dialog wewnętrzny, tłum P. Włodyga, Kraków 2004, s. 114.

42 S. Belbel, Po deszczu, s. 49.

43 Ibidem.

44 Coraz większa liczba pracowników firm, głównie amerykańskich, staje się bardziej wrażliwa na nieprawidłowości obserwowane w zachowaniach personelu kierowniczego. Tak pojawił się whistleblowing. Czy jest to donosicielstwo, czy też jednak postępowanie szlachetne, niekiedy heroiczne, stawiające na pierwszym planie lojalność wobec publiczności, a więc aktualnych lub potencjalnych klientów, oraz uczciwość i lojalność względem pracodawcy. „Rzecznicy whistleblowingu powiadają, że rzetelność jest ważniejsza od lojalności wobec złoczyńcy. Ważne jest jedynie to, by przed upublicznieniem sprawy wykorzystać możliwość jej przedstawienia i wyjaśnienia wewnątrz organizacji, dopiero gdy nie odnosi skutku, usprawiedliwione jest nadanie sprawie wymiaru szerszego"(W. Gasparski, Decyzje i etyka w lobbingu i biznesie, s. 107). 
kowicie wydany na pastwę tego niesłychanie sprężonego napędu, który można porównać z mocą rakiety, zdolnej wynieść kosmiczną kapsułę poza pole ciążenia Ziemi”"45. Bohater zostaje zdjęty ze stanowiska, a w sensie metaforycznym strącony $\mathrm{z}$ wysokości, toczy się i spada niczym lawina $\mathrm{z}$ hukiem $\mathrm{w}$ dó - $\mathrm{w}$ rozwartą szczelinę między budynkami, na dnie której rozbija się o twardy bruk ulicy. Wówczas pobrzmiewa tylko dalekie echo krzyku, a krzyk jest oznaką ludzkiej słabości, bezradności i wielkiej rozpaczy tkwiącej w człowieku. Na rozległej przestrzeni tarasu zabrakło drugiej osoby, której ręka mogłaby zagrodzić drogę wiodącą w przepaść. $\mathrm{Na}$ wysokościach wieżowców jest miejsce wyłącznie dla ludzkiej samotności. Owa samotność w bezgranicznej pustce odpowiada słowami „nie ma cię"46 - jak stwierdza Henryk Elzenberg w książce Ktopot z istnieniem.

Można uciekać się do sposobów (reorganizacja - Top Dogs) lub do czynów (akt samobójczy - Po deszczu), ale nie da się uciec od własnego ,ja”. Izolowane „ja” jest zawsze skazane na działanie sił destrukcyjnych.

Zaprezentowane rozważania nie dają wystarczających podstaw do syntezy, jednak umożliwiają sformułowanie kilku refleksji na temat ujęcia psychologicznego, socjologicznego, teatralnego i literackiego, a co się z tym wiąże - i mechanizmów interpretacyjnych kształtujących zjawisko izolacji w firmie. Interpretacja problemu izolacji w dużych korporacjach może budzić liczne wątpliwości, choć z drugiej strony pozwala zdiagnozować organizację jako instytucję totalną. Tego rodzaju dwoistość nie świadczy o ułomności tej perspektywy. Nie może być mowy o jednej, wyczerpującej teorii społecznej, gdyż zarówno przedmiot poznania, jak i podmiot poznający są historycznie zmienne. Nie ulega wątpliwości, że w ujęciach różnych badaczy i artystów izolacja jest przedstawiana jako sytuacja trudna: stresująca, lękowa, kryzysowa. Rozważania dotyczące izolacji w firmie na podstawie utworów dramatycznych Ursa Widmera Top Dogs i Sergiego Belbela Po deszczu prezentują sposoby funkcjonowania przestrzeni (wysokość), dążenie do uzyskania awansu (góra), osamotnienie (pusty gabinet) i niemożność prowadzenia rozmowy przez szklaną ścianę. Należy jednak uwzględnić również pozytywny aspekt izolacji, która może sprzyjać zachowaniu jedności grupy, stabilności i niezależności marki, a także wielopokoleniowego poczucia sukcesu. Dlatego zapewne ma rację jeden z cytowanych przez Naomi Klein przedsiębiorców, uważając, że w tym celu „musimy sami przekształcić się w markę - Markę własną [...]. Takie podejście nazywam JA S.A." ${ }^{47}$.

45 E. Ringel, Gdy życie traci sens. Rozważania o samobójstwie, tłum. E. Kaźmierczak, Szczecin 1987, s. 60.

46 H. Elzenberg, Ktopot z istnieniem, Kraków 1994, s. 243.

47 N. Klein, No logo, s. 270. 


\section{BIBLIOGRAFIA PODMIOTOWA}

Belbel S., Po deszczu, tłum. M. Mętrak-Gottesman, „Dialog” 1999, nr 4.

Widmer U., Top Dogs, tłum. J. Koenig, „Dialog” 1998, nr 8.

\section{BIBLIOGRAFIA PRZEDMIOTOWA}

Bratkowski P., Ja, firma, „Dialog” 1998, nr 8.

Chojecki M., Mowa mowy. O języku wspótczesnej humanistyki, Gdańsk 1997.

Ciosek M., Człowiek w obliczu izolacji więziennej, Gdańsk 1996.

Izolacja więzienna. Wybrane aspekty izolacji więziennej w percepcji więżniów i personelu, Gdańsk 1993.

Elzenberg H., Ktopot z istnieniem, Kraków 1994.

Fromm E., Zdrowe spoteczeñstwo, tłum. A. Tanalska-Dulęba, Warszawa 1996.

Gasparski W., Decyzje i etyka w lobbingu i biznesie, Warszawa 2003.

Goffman E., Charakterystyka instytucji totalnych, tłum. Z. Zwoliński, w: Elementy teorii socjologicznych, red. W. Derczyński, A. Jasińska-Kania, J. Szacki, Warszawa 1975.

Cżowiek w teatrze życia codziennego, thum. H. Datner-Śpiewak, P. Śpiewak, Warszawa 2000.

Gra z przechodniem. Ze Stanistawem Fiszerem rozmawia Marta Leśniakowska, „Odra” 2003, nr 7/8.

Iwanek T., Kryzys i jego odmiany, Wrocław 2004.

Klein N., No logo, tłum. H. Pustuła, Izabelin 2004.

Majer A., Miasta Ameryki. Kryzys i polityka odnowy, Warszawa 1999.

Milioner na mecie. Z Tadem Witkowiczem rozmawia Zbigniew Domaszewicz, „Gazeta Wyborcza” z 19 lutego 2007 r., DF nr 7/718.

Mitroff I., Pearson Ch., Zarzadzanie sytuacja kryzysowq, tłum. A. Janiszewski, Warszawa 1998.

Plopa M., Stres w izolacji morskiej. Psychospoteczne uwarunkowania, Gdańsk 1996.

Podgórecki A., Spoteczności wyizolowane, w: Zagadnienie marginesu spotecznego a sprawiedliwość, red. B. Hołyst, Warszawa 1977.

Rewers E., Srodowisko rozmowy, w: Pamięć, miejsce, obecność. Wspótczesne refleksje nad kulturą i ich implikacje pedagogiczne, red. J. Hudzik, J. Mizińska, Lublin 1997.

Ringel E., Gdy życie traci sens. Rozważania o samobójstwie, tłum. E. Kaźmierczak, Szczecin 1987.

Schulz von Thun F., Sztuka rozmawiania. Dialog wewnętrzny, tłum P. Włodyga, Kraków 2004.

Sztuka zarządzania. Psychologia komunikacji dla szefów i liderów, tłum. P. Włodyga, Kraków 2004.

Sposoby istnienia. Dziatanie wobec siebie i innych, red. J. Rudniański, K. Murawski, Warszawa 1988.

Sujak E., ABC psychologii komunikacji, Kraków 2006.

Tyrała P., Kierowanie, organizowanie, zarzadzanie. Zarys prakseologii, Torun 2003.

Zawadzak T., Kierowanie organizacja. Zarys problematyki, Warszawa 2003.

SŁOWA KLUCZE: szklana izolacja, izolacja przymusowa, izolacja dobrowolna, instytucja totalna, porażka, sukces 


\section{ISOLATION IN A FIRM}

The presented considerations do not propose to explicate another theory, but aim at examining the problem of isolation in both spatial (isolated space), interpersonal (isolated calls) and personal (escape from isolation) aspects. The phenomenon of isolation can be seen as a stable point of reference for the characterisation of an organisation, and for an analysis of human behaviour. The inspiration to undertake this subject came from the works of Hopper, in particular his painting Nighthawks, capturing the phenomenon of glass isolation. 'Isolation in a firm' is discussed on the basis of two dramatic plays: Top Dogs by Urs Widmer and After the Rain by Sergi Belbel. The notion of isolation in glass buildings is considered according to the approach of Mieczysław Ciosek, concerning the system of relations between man and his surroundings, which are closed in some way.

KeY worDs: glass isolation, compulsory isolation, voluntary isolation, total institution, failure, success 